\title{
Forum
}

\section{Spoken Latin in the Late Middle Ages and Renaissance Revisited}

\author{
Terence Tunberg
}

Key words: Latin, immersion, communicative, Renaissance, speaking, conversational

An article by Jerome Moran entitled 'Spoken Latin in the Late Middle Ages and Renaissance' was published in the Journal of Classics Teaching in the autumn of 2019 (Moran, 2019). The author of the article contends that 'actual real-life conversations in Latin about everyday matters' never, or almost never took place among educated people in the late Middle Ages and Renaissance. A longstanding familiarity with quite a few primary sources for the Latin culture of Renaissance and early modern period leads us to a rather different conclusion. The present essay, therefore, revisits the main topics treated by Moran.

We must differentiate Latin communication from vernacular communication (as Moran rightly does), and keep in mind that the majority of informal and conversational communication between moderately educated people (let alone the uneducated) living in the same country, and brought up with the same vernacular would have been in the native language. Even for a noble educated in the liberal arts, if he lived far removed from church, academic life, or scholarly contubernium, conversational Latin would have been a rare event. But it does not follow from these assumptions that there were no venues in which Latin was really used for extempore spoken conversation and communication. Indeed, if we pay attention to the primary materials, we learn that Latin in the Renaissance and early modern age was quite often (in certain social groups and in certain geographical regions) a vehicle for spoken and extempore communication and there were widely differing degrees of proficiency in this spoken use.

\section{Background}

After about the sixth century Latin was no longer the native speech of any people or nation. Yet the knowledge and use of Latin was retained, partly because most of the Germanic peoples, who settled in the regions that once belonged to the western Roman empire, lacked cultures based on writing. So Latin continued to be employed for public documents. Latin, of course, was also the language of the Roman church and its administration. Latin main-

Author of correspondence: Terence Tunberg. E-mail: terence.tunberg@gmail.com Cite this article: Terence Tunberg (2020). Spoken Latin in the Late Middle Ages and Renaissance Revisited. The Journal of Classics Teaching 21, 66-71. https://doi.org/10.1017/ S2058631020000446 tained its role as the primary language by which the liberal arts and sciences were communicated throughout the Middle Ages and Renaissance. Latin was the language of teaching and disputation in the schools and universities founded during the medieval centuries. Throughout this immensely long period of time, the literate and educated were, of course, always a small percentage of the total population. But for virtually all of the educated class Latin was an absolute necessity; and for nearly all of them Latin had to be learned in schools. Their goal was not merely to be able to read the works of Latin authors, the Latin sources of the liberal arts and theology, but also to be able to use Latin themselves as a language of communication in writing and sometimes in speaking. But, although people typically learned Latin in the Middle Ages and Renaissance in order to use it, and although new Latin words were coined for new entities, the syntactical and idiomatic norms for expression in Latin were not evolving in the same way they were evolving in French, German, and other vernacular tongues. The norms of Latin (not always observed, of course, with perfect consistency) were fixed in texts. For the Middle Ages, the normative texts were the Scriptures and Church Fathers. Since the Renaissance, the standard for prose was found in the works of Caesar, Cicero, Livy, and others of their contemporaries, or in works of later Latin writers (including NeoLatin authors) who followed the usage of these classics.

\section{Spoken Latin in schools}

Thanks to recent historical scholarship, we know quite a lot about how Latin was taught to children in different regions throughout the medieval and early modern periods. As we might expect, training in Latin differed somewhat from region to region and changed over time (Tunberg, 2012, pp.19-46). ${ }^{1}$ But certain pedagogical practices existed in many different regions and remained in use for many centuries. Although training the young to express themselves in Latin was one of the primary goals of education, and although up to the middle part of the 17th century nearly all grammatical and rhetorical handbooks produced to assist this training were written entirely in Latin, the very beginning stages of learning Latin usually did not involve total immersion. These beginning stages were devoted to instruction in grammar, which was then a much simpler science than the detailed rules contained in grammar books published in a later age (from the 18th century onward). Medieval and early modern teachers made extensive use of their vernacular 
languages to help young children learn the fundamentals. But the use of Latin as the meta-language of teaching rapidly increased as children progressed. ${ }^{2}$ What we might call 'immersion' typically began after the second year of instruction (and even after this, as manuscript glosses and early printed texts show, teachers might sometimes resort to a well-known vernacular word or phrase to explain obscure Latin words). From the second year on, Latin was usually (especially in Germany, the Low Countries, France and middle Europe) the only permitted spoken language on school premises. This progression was also typical of the Jesuit schools, which began to proliferate in the late16th century: the obligatory use of Latin not only for teaching, but also for conversation on school premises is specifically and repeatedly endorsed in many parts of the famous Jesuit Ratio studiorum (Lukács, 1986, pp. 131$132,199,242,245-246,260,418)$. The exclusive employment of Latin as the language of communication within the academy is commonly listed among the requirements for academic probity in school and university statutes. Violation of this requirement could be grounds for punishment or expulsion (for just a few examples: Hoven, 1979; Watson, 1908, pp. 186, 310-312, 316-318, 346). Despite these severe sanctions, as we know from many testimonies, the laws requiring Latin discourse in schools were often violated or even ignored. ${ }^{3}$ Nevertheless, such laws and statutes arose from a perceived need to maintain a Latinate environment. Students, of course, when they went home, used their native languages with family and friends. But they commonly spoke Latin with fellow students and teachers in the academy - and not merely in the classroom. Our sources reflect the fact that this student Latin discourse varied widely. Sometimes it was more or less correct. Often, as we might expect from young beginners, it was barbarous.

Closely allied with the obligation to speak only Latin on the premises of the academy was the horribly repressive practice, certainly widespread in France and in the German speaking areas (and probably elsewhere too), of offering rewards to a few select students, known as Corycaei, to act as informers against any fellow student who dared to use the vernacular language when out of earshot of the schoolmasters. The rationale for this tyrannical system is set forth in uncompromising terms by Ioannes Posselius, a German pedagogue who flourished in the later 16th century and spent part of his life as professor of Greek at the University of Rostock:

Just as these writing exercises must be accurately and assiduously practiced, so also the practice of speaking Latin should in no way be neglected. In order that this may be better maintained, guardians or 'Coricaei' must be appointed, who take note of lower level students speaking German and more advanced students employing Germanisms or solecisms or indeed barbarisms, and report them to the teacher... Each practice - that of writing in Latin and that of speaking in Latin - must thrive in Latin classes: nor can one be separated from the other. ${ }^{4}$

These Corycaei drew their nickname from the narratives of Pliny, Strabo, and other ancient writers, who described a people situated on a promontory in Cilicia named Corycus, who used to spy on shipping and give pirates intelligence about the movements of ships (Schottennius, 2007, p. 488-489: Tunberg, 2014a, pp. 23-27).

\section{The colloquia - model dialogues for Latin conversation}

During the 15th and 16th century a fundamental change in European culture affected the way Latin was taught and used; namely the revival of classical norms in all the arts. In this movement, which had its origins in Renaissance Italy and gradually spread to northern Europe, Latin was fundamental. The new cultural sensibility of humanism demanded that contemporary Latin expression be reformed to accord with the syntactical and idiomatic norms observable in the works of classical pagan Latin authors who had flourished in the period that extended from the lifetime of Cicero to that of Quintilian. ${ }^{5}$ The humanist teachers did not necessarily despise all of patristic and medieval Latin (indeed, some scholars, such as Erasmus, expressed admiration for the language of Lactantius and Jerome) but they rejected the specialised Latinity of scholastic law, theology, and dialectic, the most popular disciplines taught in the medieval universities (the earliest of which had been founded in the late 12th century). The Latin used in the teaching and dissemination of these academic disciplines had become a distinctive idiom, which was often very far removed in syntax, semantics and vocabulary from the norms of classical and even patristic Latin. The humanist grammarians also took aim at another target, which they considered to be closely connected with the jargon of scholastic dialectic, namely the barbarous spoken Latin of students often heard in schools. Macaronic phrases from students are ridiculed by Mathurinus Corderius, a distinguished Neo-Latin writer, teacher and reformer, in his De corrupti sermonis emendatione libellus (1535). No less scornful are the words of Franciscus Sylvius Ambianus, a 16th-century French grammarian:

... the teachers bar those students from the use of $<$ their $>$ native language so harshly that, if any $<$ students $>$ are caught speaking the $<$ native $>$ language by secretly planted observers, they suffer a severe punishment. Since, therefore, they are forced to speak Latin, they assume that all language is Latin that has the form of Latin. This is the reason why they invent for themselves many barbarous expressions. The teachers make no objection, provided that the language isn't the mother tongue. Students who have been enrolled in courses in dialectic add quite a bit of impetus to the faulty way of speaking Latin. These people don't worry about what kind of language, what style of conversation they use in discourse, provided there is comprehension. So in my perspective, let the native language of the students have more value than barbarous Latin speech [rusticus <sermo $>$ ]: and teachers should put more effort into enabling students to speak correct, idiomatic Latin, than into preventing them from using the vernacular language. ${ }^{6}$

The humanists adopted various strategies to counter these corrupting (as they saw it) influences on Latin. A number of celebrated Italian writers of Latin, who adopted a consciously Ciceronian style, were said to avoid the conversational use of Latin entirely, a squeamishness which Erasmus mocks mercilessly in his satiric dialogue Ciceronianus. ${ }^{7}$ In fact this fastidiousness of the Italian Ciceronians, even if perhaps distorted by rumour, seems to be consistent with a real regional difference in pedagogy. Extempore discourse in Latin was stressed much more in Germany, Low Countries, France, middle Europe than in Spain or Italy, and this may be because teachers in Italy and Spain feared that excessive interference from their native languages (being similar to Latin) would encourage corrupt extempore student discourse (Tunberg, 2012, pp. 53-61). Perhaps as a result of this regional difference, there are repeated testimonies that northern European scholars travelling in Italy conversed in Latin much more fluently than the 
Italians. ${ }^{8}$ Others, especially in Northern Europe (and in this group there were also many Ciceronians), took a different tack: they strove to reform the conversational Latin itself. This attempt is manifest in the publication of collections of short dialogues, often called colloquia familiaria, designed as models for daily conversation in Latin. Similar works had been written in earlier centuries. A few Latin dialogues on quotidian topics, which seem to be models for learners of colloquial Latin, survive from late Antiquity and the early Middle Ages (Dickey, 2016; Gwara, 1996; Stevenson, 1929; Dickey, 2010 and 2012).

But most of the early modern colloquia stand apart from these earlier works in several important ways. First, these humanistic dialogues were written by well known authors, such as Erasmus, Vives, and Pontanus, and in vast numbers: in the 16th century alone scores of authors published thousands of colloquia. Secondly, while the early modern colloquia are indeed devoted to topics typical of contemporary daily life, they present these subjects in a 'classicising' Latin that (with the occasional admission of medieval Latin words for non-ancient entities and institutions) more or less accords with norms of Latin prose produced in the period between Cicero and Quintilian. ${ }^{9}$ We should also keep in mind that the sophisticated Colloquia of Erasmus usually read today (which are the final versions of dialogues revised and republished many times by Erasmus) are also works of social satire, and are therefore quite removed from the typical genre of colloquia represented by the dialogues of Mosellanus, Pontanus, Schottennius, Corderius, and many others, ${ }^{10}$ which are almost exclusively focused on presenting a large supply of classical (or classicising) Latin phrases appropriate for everyday situations and topics, especially those that would occur in the lives of schoolboys.

\section{What sort of 'colloquial' Latin do we find in the colloquia?}

Let us stress that for the authors of these early modern colloquia the colloquial and (unrecoverable) domestic speech of the ancient Romans was never the target, and is hardly relevant. ${ }^{11}$ The goal in the humanist age was to speak extempore and with a simple syntax in a Latin that was reasonably close to the literary Latin observable in the works produced in the 'golden' and 'silver' age, and close to the usage of moderns who imitated that Latinity. ${ }^{12}$ In fact, something not dissimilar had begun to exist in the Roman empire, since the speech of the cultivated already differed quite a bit from vulgar Latin - hence boys training for careers among the elite had to learn the right way to speak from the grammarian and rhetorician. But in the humanist age (as in the preceding medieval era) the vulgar speech was a totally different language. Spoken Latin, therefore, meant speaking extempore in an artificial idiom - a 'dead' language, if anyone wants to use that terminology - whose syntactical, grammatical, even idiomatic norms were entirely enshrined in literature and codified by well-trained teachers. New nouns and adjectives might be occasionally added, but the grammatical structure and norms of expression had to be carefully preserved. As Erasmus himself put it: 'I want the rules to be few, but excellent - in my view the rest is to be sought from <the usage of $>$ the very best writers, or from the conversational usage of those who speak like those authors wrote. ${ }^{13}$ But there is nothing absurd or impossible about this situation, or in using a language of this kind. The situation of Sanskrit, to mention one example, was for centuries not dissimilar. The final real proof is Latin itself, which continued as an active language and as the medium for an astoundingly rich literature for about a millennium and a half after it ceased to be anyone's mother tongue.

\section{Did the colloquia offer an alternative to grammatical instruction?}

The early modern colloquia were not designed for the beginning stages of grammatical instruction. They were meant for students who had already learned the fundamentals and were deemed ready to begin some reading. Students might begin to read the colloquia along with short and simple texts from the ancient patrimony, which sometimes included a few of Cicero's letters. But the colloquia, if their language was thought to be pure, might even be preferred as a 'first reader', as the Jesuit master Iacobus Pontanus explains:

So if the language of the Dialogues is, as it should be, that of the ancient authors, well-arranged, clear, correct, polished, and seasoned with wit, since it is also discourse appropriate for friendly gatherings (familiaris), shouldn't we believe that through reading or hearing these dialogues there will be a good deal of progress <on the part of the students $>$ towards speaking and writing? ${ }^{14}$

The colloquia, moreover, according to Pontanus, deal with subjects that are easier for young students to understand than the topics treated in Cicero's letters:

One must admit that the affairs dealt with in Cicero's letters are understood by the youth and young minds with more effort and not as completely as the themes that occur in Dialogues - there is nothing more usual, better known, more apparent and familiar than the subject matter and situations $<$ treated in $>$ these dialogues. ${ }^{15}$

The manifestly didactic function of these dialogues was considered to be two-fold, and this double purpose is expressed with remarkable consistency in the prefaces to various collections of colloquia: namely, to teach good Latinity, but also good morals. Erasmus, speaking of one of the earlier editions of his own colloquia, puts it this way: 'In that little book I am not presenting the tenets of religion: I'm presenting expressions for speaking Latin, even if there have been mixed in along the way certain elements that contribute to good morals....' 16 The colloquia familiaria could be lectured on and explained by a teacher, just like the works of any Latin author: they might be also be used as models for student conversational Latin sessions on specific themes (and one teacher explains his practice of instituting such sessions just before regular class time) ${ }^{17}$ Perhaps they were sometimes acted out by students like short plays. ${ }^{18}$

It is impossible to know, of course, whether all the efforts of these teachers and grammarians had any effect on the general level of the spoken Latin of young students. Laments about barbarous and macaronic conversational Latin persisted throughout the early modern age, and indeed down to the present time. However, as far as written production was concerned, it is obvious that the efforts of the humanists were generally successful. With the exception of a few restricted fields like canon law, in which the Latinity of medieval scholastic disciplines persisted, and with due allowance for neologisms in vocabulary and wide range of possible models, the revived classical norms of expression advocated by the humanists are clearly prevalent in the vast bulk of Latin writing produced from the 16th century onward.

\section{Speaking Latin and writing in Latin}

If we may generalise, the spoken use of Latin in the early modern era was closely tied to, and even ancillary to the written use. Writing 
good Latin might justly be considered the primary purpose of humanist education, and the relationship between written expression and extempore oral discourse was not rarely discussed by humanist teachers. Ioachimus Fortius, a Belgian grammarian and pedagogue, who had met Erasmus, won some notoriety by suggesting that there was a significant gap between written and spoken expression. The subjects discussed in daily conversation, argued Fortius, typically differ from the topics about which one would write a treatise or history. A chorus of humanists, including such eminent Jesuit teachers as Iacobus Pontanus and Antonius Van Torre, and the philologist Henricus Stephanus (Henri Estienne), strongly disagreed, pointing out that much writing (especially letters) is in a simple register that is close to conversation. More importantly, they argued, the ability to speak extempore on any subject helps one to write faster, and to find the right word or phrase for a given topic with much less effort (Tunberg, 2012, pp. 51-52, 57-58, 82-84). ${ }^{19}$ Some teachers and grammarians, therefore, valued conversational proficiency in Latin simply because they thought it contributed to a total and instinctive command of the language of their profession.

\section{Spoken Latin outside schools and universities}

Although Latin was conspicuous as the language of schools and universities across Europe (and of the first academies founded in the New World), it is clear that even outside the strictly academic environment many humanists used Latin for spoken communication with their peers. ${ }^{20}$ Erasmus, to mention just one example, although he spent years in England, seems to have learned very little English. ${ }^{21}$ While he sojourned in that country, of course, he made the most of the company of Thomas More and other Latinate friends. Erasmus, in fact, describes Thomas More's fluency in conversational Latin:

You would hardly find another person more comfortable in free conversation: to such an extent does his ready tongue obey his ready intellect. That intellect is at the fore and everywhere ahead of the game, and his memory is well equipped: and since that memory has all the words ready for use (i.e. as if in ready cash), it instantly puts forth whatever the situation or subject matter demands. ${ }^{22}$

Erasmus had similar networks of friends in other lands with whom he communicated easily, and he rarely seems to have encountered the sort of difficulty which once arose in Italy when Bernardus Oricellarius ( Rucellai), a scholar of Sallust and a notable humanist, addressed Erasmus in Italian. Replied Erasmus in Latin: 'You are addressing a deaf man, esteemed sir, I am just as ignorant of the vernacular tongue of your country as I am of the Indian language. But try as he might, says Erasmus, 'I could never extort a $<$ single > Latin word from him. ${ }^{23}$

It is not surprising that ability to converse in Latin, the international language of the educated, was commended by some humanist teachers as a useful skill for travellers wishing to communicate with the educated residents of different linguistic regions. ${ }^{24}$ Latin indeed served as a means of communication in church councils, diplomatic circles, in meetings of academics from different regions. ${ }^{25}$ But, although several 'restored' pronunciations were proposed by humanist scholars (including Erasmus in De recta Latini Graecique sermonis pronuntiatione), none of these was generally adopted, ${ }^{26}$ and different national modes of vocalising Latin could make mutual understanding initially difficult. A little time would be needed to get used to a variant pronunciation. The problem was often worse when French or English people (especially after the 'great vowel shift' in English) spoke Latin, whose habits of enunciating could be so deviant from those of other Europeans as to constitute a serious impediment to comprehension. A fairly common expedient (used, for example, by John Milton) was to adopt an Italianate pronunciation of Latin, which was apparently quickly intelligible in quite a wide range of regions. ${ }^{27}$

\section{Spoken Latin after the Renaissance?}

The 17th and 18th centuries saw a dramatic increase in the use of the national languages for the arts and sciences, fields of communication in which Latin had previously been the primary language. A new cultural reality evolved, in which the ability to produce written texts in Latin for an international learned elite became steadily less necessary. This cultural and intellectual evolution, along with the social factors that contributed to it, have been thoroughly treated by many historians. ${ }^{28}$ For our present purpose, it is enough to point out that the practice of vocal conversation in Latin, especially in schools outside the Catholic Church, seems to have steadily eroded along with the declining use of Latin for written publication. The national languages were being used for lectures and classes at major universities in many parts of Europe by the early 18th century. ${ }^{29}$ The new academic environment existed even in Germany, where the use of Latin for major publications tended to be retained longer than in France or Italy (Minkova, 2014: Tunberg, 2012, pp. 34-38; 91-96).

It is worth pointing out, however, that the spoken use of Latin never entirely vanished (Minkova, 2014). This custom continued to exist in many German gymnasia and in some Dutch schools during the 19th century (Tunberg, 2012, p. 93: Van Bommel, 2013). Latin continued to be the language of teaching in seminaries of the Catholic Church until the time of the second Vatican Council in the 1960s. But these are traditions or vestigial practices left over from an age when Latin had been widely used as a written language for publication in the arts and sciences.

Yet in our time, in the second half of the 20th century and the first part of the 21st century, there has been - partly among members of the Roman church, but also (and in large part) among educators and others unconnected with Roman Catholic circles - a surprising revival of interest in communicative Latin. This is a story worth telling, but it takes us beyond the parameters of the present discussion.

\section{Notes}

1 For a selected bibliography pertaining to Latin education in the Medieval and early modern periods, see Minkova and Tunberg (2012, p.113).

2 Modern experts in Latin pedagogy sometimes distinguish between the natural or direct method of teaching elementary language and the grammatical approach. As shown by Van Bommel (2013), such a distinction is almost meaningless if applied to the Latin pedagogy of two centuries ago - let alone the pedagogy of the 16th and 17th centuries.

3 In Renaissance universities conditions could range from complete adherence to Latin usage, such as that described by Jacob Wimpfeling at Erfurt: 'I still recall that all students... in the splendid University of Erfurt... having been obliged to the constant use of Latin could non utter German discourse without penalty' ('Memor adhuc sum in clarissimo studio Erfurdensi omnes scholasticos... ad assiduum Latinitatis usum coactos Theutonicum sermonem impune effari non potuisse'. Wimpfeling, 1514, f. iiiiv), to the laxity observed at Salamanca at the end of the 16th century, where Castilian was the language for some of the teaching. For these and many other testimonies see Tunberg (2012, pp. 33-38).

4 'Ut autem haec scribendi exercitia diligenter et fideliter colenda sunt, sic et Latine loquendi exercitatio [...] nequaquam negligi debet. Quod quo rectius fieri possit, custodes seu 'coricaei' constituendi sunt, qui et iuniores Teutonice loquentes 
et grandiores vel Germanismis vel soloecismis vel denique barbarismis utentes annotent et ad magistrum deferat... Utrumque enim exercitium Latine scribendi et loquendi in Latinis scholis vigere debet, nec alterum ab altero separari potest' (Posselius,1589, p. 145)

5 The ancient Latin prose writers who had flourished from Cicero's period to that of Quintilian were defined as exemplary by Laurentius Valla in his famous Elegantiae (1538), a monumental work on Latin usage that was completed shortly before 1450, which became one of the most influential handbooks on Latin composition during the early modern period. The Elegantiae was reprinted again and again throughout Europe during the 16th and 17th centuries.

6 '... magistri usu sermonis vernaculi eos $<$ discipulos $>$ tam severe prohibent, ut, si qui ab observatoribus clam dispositis hoc sermone loqui deprehendantur, poenas graveis expendant. Igitur quoniam Latine loqui coguntur, Latinum sermonem putant omnem eum qui Latini formam habeat. Quae causa est, ut barbara multa ipsi sibi confingant... Nihil improbant magistri, modo ne sit sermo domesticus (...) Ei autem loquendi vitiosae consuetudini vim non parvam adiungunt $i i$, qui dialecticae auditores sunt, qui qua lingua, quo sermone loquantur, modo se intelligant, securi sunt (...) Quare apud me auditorum sermo vernaculus quam rusticus praeponderet, laborandumque praeceptoribus potius est, ut proprie Latineque loquantur discipuli, quam ea ne lingua utantur vernacula...' Sylvius (1545) f. iiir.

7 Erasmus, Desiderius, Ciceronianus http://agoraclass.fltr.ucl.ac.be/concordances/erasme_ciceronianus/texte.htm. The whole text of the Ciceronianus may be conveniently consulted in this website prepared by the Université Catholique de Louvain. See section 356 of this edition for the passage alluding to ex-tempore expression in Latin.

8 Spoken Latin from the 16th to the 18th centuries was much rarer in Italy than in transalpine Europe, except (perhaps) in the coteries of the Roman church. Many, many testimonies to this regional difference are extant (Tunberg, 2012, pp. 49-59).

9 Only the very earliest of the colloquia that might be classified as early modern, such as those composed by Paulus Niavis in the 15th century, might be excepted from this statement. In these earlier dialogues the classicising impulse is much less manifest, and their language reflects the standards of Latinity typical of medieval universities.

10 An archive of early modern colloquia, comprising more than 600 dialogues, can be found at the following website: http://www.stoa.org/colloquia/.

11 The whole question of the interplay between colloquial and literary Latin in antiquity is highly complex. See the interesting papers on this topic edited by Dickey and Chahoud (2010). Of course, as pointed out by Moran (2019), we lack a complete knowledge of all aspects of the colloquial and domestic speech of the ancient Romans.

12 Quite different are the medieval colloquies of Aelfric, which offer phrases that apparently passed for normal Latinity in an 11th-century Anglo-Saxon monastery (Gwara, 1996). Even more different are the few surviving conversational dialogues from the Roman era, which are focused on the current idiom of popular Latin appropriate for traders, businessmen and the like. In other words, these Roman colloquia are aimed at what was a still evolving ('living', of course) language (Dickey, 2016).

13 'Praecepta volo esse pauca sed optima-quod reliquum est arbitror petendum ex optimis quibusque scriptoribus, aut ex eorum colloquio, qui sic loquuntur ut illi scripserunt' (Allen, IV, p. 209).

14 'Ergo si Dialogorum sermo totus fuerit (esse autem debet) antiquus, concinnus, dilucidus, proprius, lautus, ac salibus conditus, cum sit etiam familiaris, nonne ad loquendum scribendumque haud mediocriter iis sive legendis, sive audiendis profectum iri credendum est?' (Pontanus, 1599, B3v).

15 '...fatendum est res iis epistulis $<$ Ciceronis $>$ inclusas laboriosius et imperfectius a pueritia tenerisque ingeniis comprehendi, quam quae cadunt in Dialogos, quorum argumentis atque rebus nihil est usitatius, nihil notius, nihil magis obvium atque domesticum ...' (Pontanus, 1599, B2).

16 '... in eo libello non trado dogmata fidei, sed formulas loquendi Latine: tametsi quaedam admixta sunt obiter quae faciunt ad bonos mores' (Allen, V, p. 91).

17 As indicated in the preface to Book I that we find in Corderius (1819, pp. 3-4). The preface in this late edition was perhaps composed by Corderius himself certainly by someone accustomed to using these dialogues in teaching.

18 For more evidence indicating how the colloquia were used in early modern Latin pedagogy, see Tunberg (2020) and (2014b).

19 See also the remarks of Posselius quoted above in note 4 .
20 This use of Latin as a spoken language outside academic life was more prevalent north of the Alps than in Italy itself. See note 8.

21 For Erasmus' knowledge of national languages, see Chomarat (vol. I, 1981) 27-157.

22 'Vix alium reperias qui felicius dicat ex tempore: adeo felici ingenio felix lingua subservit. Ingenium praesens et ubique praevolans, memoria parata; quae cum omnia habeat velut in numerato, prompte et incontanter suggerit quicquid tempus aut res postulat' (Allen, IV, p. 21). Conversational Latin in these circles of litterati might often be not merely correct, but even eloquent and rhetorically adept - if we accept the judgment of contemporaries. For many other testimonies, see Tunberg (2012, pp.87-89).

23 'Surdo loqueris, vir praeclare, vulgaris linguae vestratis tam sum ignarus quam Indicae...' '<Sed > verbum Latinum numquam... ab eo extundere potui...' The anecdote comes from Erasmus' Apophthegmata (LB IV) 363D-E.

24 '... If a person (apparently Italian) sojourns among these peoples (meaning Germans, French and Spanish) without knowledge of their local language, unless he would use the Latin language as a go-between, he could do nothing, transact no business with them, but would be forced to be silent and entirely speechless.' ('Apud has. . .gentes, si quis domestici et vernaculi ipsorum sermonis ignarus versatur, nisi Latino sermone interprete utatur, nihil possit agere, nihil cum illis contrahere, sed mutus et elinguis prorsus esse cogatur'). This passage is from the Epistula nuncupatoria or Dedicatory Letter to an expanded edition of Nizzoli's famous Cicero lexicon (Nizzoli, 1576, f. A 4r). For other testimonies on the value of Latin as a 'lingua Franca', see Tunberg (2012) 56, 81.

25 'How would there be discussion in the august and sacred college of Cardinals about serious issues - issues which is it often useful to be revealed to those $<$ officials $>$ alone who have the right to pronounces a decision, if as many interpreters had to be employed, as are nationalities of which the assembly is composed?' ('Quomodo in illo augusto ac sacrosancto Cardinalium collegio de gravissimis rebus et quas saepe iis solis notas esse expedit, qui sententiae dicendae ius habent, deliberaretur, si quot ex nationibus consessus ille constat, totidem interpretes adhibendi forent?' Muretus, vol. I, 1834-1841, p. 413.

26 Erasmus himself seems never to have used the phonetic system he proposed. 27 For many more details and sources see Tunberg (2005) and (2012, pp. 69-77. See also Sacré (2014).

28 For a summary of the cultural factors and sources, see Tunberg (2012) 91-93. 29 When Ludvig Holberg, the eminent Danish writer, visited England in the early 18th century, he was surprised to find that the custom of speaking Latin (something still existing at that time in many European Universities) was moribund among faculty and students at the University of Oxford (Holberg, 1737, p. 35).

\section{References}

Chomarat J (1981) Grammaire et rhétorique chez Erasme. 2 vols. Paris: Société d'Edition "Les Belles Lettres."

Corderius M (1535) De corrupti sermonis emendatione libellus, Maturino Corderio autore. Lugduni: apud Seb. Gryphium.

Corderius M (1819) Maturini Corderii Colloquia scholastica commodiori (sic) nunc ordine quinque libris composita et quibusdam aliis ad commodiorem juventutis institutionem pertinentibus operā Ramberti Horaei exornata. Editio nova et correcta. Neocomi: apud C.-H. Wolfrath typographum.

Dickey E (2016) Learning Latin the ancient way: Latin textbooks from the ancient world. Cambridge: Cambridge University Press.

Dickey E (Ed.) (2015) The Colloquia of the Hermeneumata Pseudodositheana Volume II : Colloquium Harleianum, Colloquium Montepessulanum, Colloquium Celtis, and Fragments. Cambridge Classical Texts and Commentaries. Cambridge: Cambridge University Press.

Dickey E (Ed.) (2012) The Colloquia of the Hermeneumata Pseudodositheana. Volume 1: Colloquia Monacensia-Einsidlensia, Leidense-Stephani, and Stephani. Cambridge Classical Texts and Commentaries. Cambridge: Cambridge University Press.

Dickey E and Chahoud E. (Eds.) (2010) Colloquial and Literary Latin. Cambridge: Cambridge University Press.

Erasmus, Desiderius

Allen = Allen P S (Ed.) (1906-1965) Des. Erasmi Roterodami opus epistularum. 12 vols. Oxford: Oxford University Press.

$L B=$ Clericus J (Ed.) (1703-1706) Des. Erasmi Roterodami opera omnia, ed. I. Clericus. 12 vols. Lugduni Natavorum (Leiden). 
Gwara S (Ed.) (1996) Latin colloquies from pre-conquest Britain. Toronto Medieval Latin Texts. Toronto: Ponitifical Institute of Mediaeval Studies.

Holberg L (1737) Ludovici Holbergii opuscula quaedam Latina, Epistola I. Cuius nova haec editio prioribus est emendatior. Epistola II. Quinque libri epigrammatum. Lipsiae: sumptibus B. Hieron. Christ Paulli Viduae.

Hoven R (1979) Programmes décoles latines dans les Pays-Bas et la Principauté de Liège au XVIe siècle. In P Tuynman, G C Kuiper and E Kessler (Eds.) Acta conventus neo-latini Amstelodamensis. Proceedings of the Second International Congress of Neo-Latin Studies. Amsterdam 19-24 August 1973. München: W. Fink.

Leonhardt J (2013) Latin: Story of a World Language. trans. K. Kronenberg. Cambridge, MA: Harvard University Press.

(Lukács) Ratio atque institutio studiorum societatis Iesu (1586, 1591, 1599), ed. L. Lukács, S. I., in Monumenta historica societatis Iesu, 129, Tom. V (Romae, 1986).

Minkova M (2014) Conversational Latin: 1650 to the Present. In P Ford, J Bloemendal and C Fantazzi (Eds.) Brill's Encyclopedia of the Neo-Latin World. Leiden: Brill, 83-86.

Minkova M and Tunberg T (2012) Active Latin: Speaking, Writing, Hearing the Language. New England Classical Journal 39.2, 113-128.

Moran J (2019) Spoken Latin in the Late Middle Ages and Renaissance. Journal of Classics Teaching, 20.40, 20-24.

Muretus M-A (1834-1841) M. Antonii Mureti opera omnia, edited by C. H. Frotscher. 3 vols. Lipsiae: Serginana Libraria.

Nizzoli M (1576) Nizolius sive Thesaurus Ciceronianus, post Mar. Nizolii, Basilii Zanchi, et Caelii Secundi Curionis...operas, per Marcellum Squarcialupum Plumbinensem, cum insigni accessione... digestus et illustratus. Basileae: ex officina Hervagiana.

Pontanus I (1599) Jacobi Pontani de societate Iesu Progymnasmatum Latinitatis, sive dialogorum volumen primum, cum annotationibus. De rebus literariis. Editio octava. Ingolstadii: excudebat Adam Sartorius.

Posselius J (1589) Johannis Posselii Orationes Octo, Habitae In Publicis Congressibus Academiae Rostochiensis. Francofurdi Ad Moenum: apud Ioan. Spiessium.

Schottennius H (2007) Schottennius Hermannus Schottennius Hessus, Confabulationes tironum litterariorum (Cologne, 1525), edited by P. Macardle. Durham Modern Language Series. Manchester: Manchester University Press.
Sacré D (2014) Pronunciation of Latin. In P Ford, J Bloemendal and C Fantazzi (Eds.) Brill's Encyclopedia of the Neo-Latin World. Leiden: Brill, 161-170.

Stevenson W H (1929) Early scholastic colloquies. Oxford: Oxford University Press.

Sylvius F (1545) Progymnasmatum in artem oratoriam Francisci Sylvii Ambiani viri disertissimi centuriae tres. Nunc quam antea emendatiores in lucem editae. Venetiis: apud Nicolaum de Bascarinis sumptu Melchioris Sessae.

Tunberg T (2020) Quibus modis colloquiorum libelli a praeceptoribus ad pueros instituendos saeculis xvi et xvii adhibiti sint, Acta Academiae Latinitati fovendae: de colloquiis. Available online: https://academialatinitatifovendae.com/de-colloquiis. Accessed 22 September 2020.

Tunberg T (1, 2014a) Conversational Latin to 1650. In P Ford, J Bloemendal and C Fantazzi (Eds.) Brill's Encyclopedia of the Neo-Latin World. Leiden: Brill, 75-82.

Tunberg T (2, 2014b) Colloquia familiaria aetate litterarum renatarum scripta ne spernamus. In P P Aspaas, F Nilsen and S Albert (Eds.) Liber festivus Sunnivae des Bouvrie, Nordlit 33: 311-319.

Tunberg T (2012) De rationibus quibus homines docti artem Latine colloquendi et ex tempore dicendi saeculis XVI et XVII coluerunt. Supplementa Humanistica Lovaniensia 31. Leuven: Leuven University Press, Leuven.

Tunberg T (2005) Observations on the Pronunciation of Latin during the Renaissance. The Classical Outlook 82.2: 68-71.

Valla L (1538) Laurentii Vallae De Linguae Latinae Elegantia Libri Sex. Eiusdem De Reciprocatione Sui, \& Suus, libellus adprime utilis. Lugduni: apud Seb. Gryphium.

Van Bommel S P (2013) Classical Humanism and the Challenge of Modernity. Debates on classical education in Germany c. 1770-1860. Utrecht University: $\mathrm{PhD}$ dissertation.

Watson F (1908) The English grammar schools to 1660: Their curriculum and practice. Cambridge: Cambridge University Press.

Wimpfeling J (1514) Diatriba de proba institutione puerorum in trivialibus et adolescentum in universalibus gymnasiis; De interpretandis ecclesiae collectis Regulae XVI; De ordine vite sacerdotalis. Hagenoae: apud Henricum Gran. 